\title{
Congestive radiculopathy
}

Figure T1-weighted sagittal MRI, T2-weighted parasagittal MRI, and coronal reconstructed CT
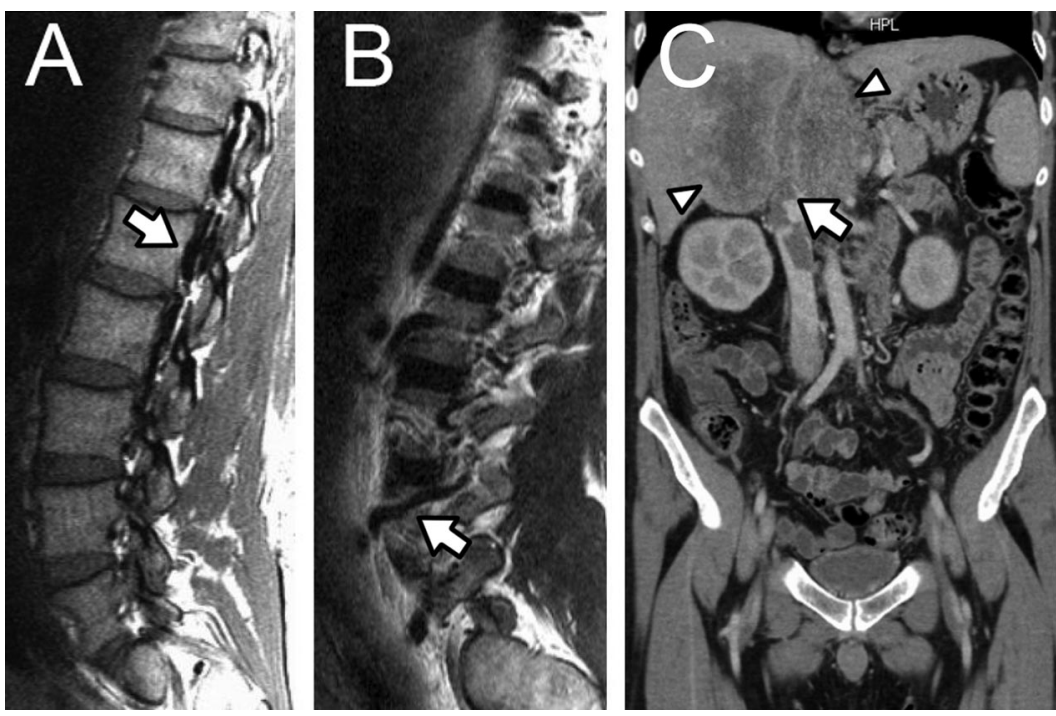

T1-weighted sagittal MRI: enlarged lumbar epidural veins (arrow) compressing the dural sac (A). T2-weighted parasagittal MRI: enlarged lumbar veins entering the neuroforamina (arrow) in TH12-L5 (B). Coronal reconstructed CT: extensive thrombosis of the inferior vena cava (arrow). Hypodense intrahepatic metastatic lesion (arrowheads) (C).

A previously healthy 34-year-old man was referred for suspected lumbar canal stenosis. He presented with a 2-month history of exercise-induced lower back pain radiating to the thighs and a sensation of constriction in the lower abdomen, readily subsiding in the supine position. Neurologic examination was normal. MRI showed engorged venous vessels but no lumbar stenosis or disc protrusion (figure). He subsequently developed jaundice and generalized pruritus. Abdominal imaging revealed large intrahepatic lesions compressing an extensively thrombosed inferior vena cava. Histologic diagnosis was moderately differentiated adenocarcinoma. Congestive radiculopathy should be considered especially in younger patients with pain localization atypical of lumbar canal stenosis. ${ }^{1}$

Simon N. Jacob, MD, Till Diergarten, MD, and Arthur Melms, MD, Tübingen, Germany Disclosure: The authors report no conflicts of interest.

Address correspondence and reprint requests to Dr. Simon N. Jacob, Department of Neurology, University of Tübingen Medical School, Hoppe-Seyler Str.3, 72076 Tübingen, Germany; simon.jacob@klinikum.uni-tuebingen.de

1. Paksoy Y, Gormus N. Epidural venous plexus enlargements presenting with radiculopathy and back pain in patients with inferior vena cava obstruction or occlusion. Spine 2004;29:2419-2424. 


\section{Neurology}

\section{Congestive radiculopathy}

Simon N. Jacob, Till Diergarten and Arthur Melms

Neurology 2008;70;734

DOI 10.1212/01.wnl.0000302183.86651.e6

This information is current as of February 25, 2008

\section{Updated Information \&} Services

References

Subspecialty Collections

Permissions \& Licensing

Reprints including high resolution figures, can be found at: http://n.neurology.org/content/70/9/734.full

This article cites 1 articles, 0 of which you can access for free at: http://n.neurology.org/content/70/9/734.full\#ref-list-1

This article, along with others on similar topics, appears in the following collection(s):

All Clinical Neurology

http://n.neurology.org/cgi/collection/all_clinical_neurology All Oncology

http://n.neurology.org/cgi/collection/all_oncology

All Spinal Cord

http://n.neurology.org/cgi/collection/all_spinal_cord

MRI

http://n.neurology.org/cgi/collection/mri

Information about reproducing this article in parts (figures,tables) or in its entirety can be found online at:

http://www.neurology.org/about/about_the_journal\#permissions

Information about ordering reprints can be found online:

http://n.neurology.org/subscribers/advertise

Neurology ${ }^{\circledR}$ is the official journal of the American Academy of Neurology. Published continuously since 1951, it is now a weekly with 48 issues per year. Copyright . All rights reserved. Print ISSN: 0028-3878. Online ISSN: 1526-632X.

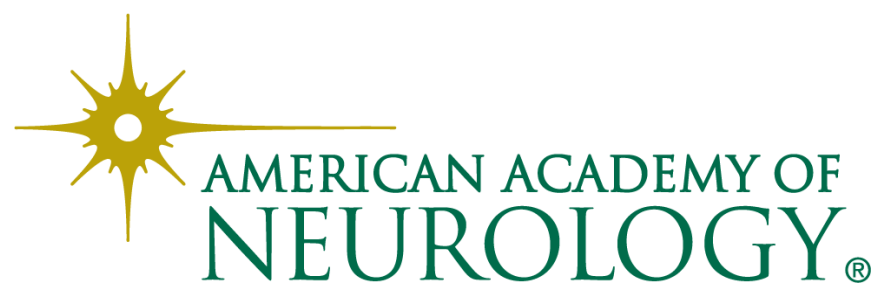

